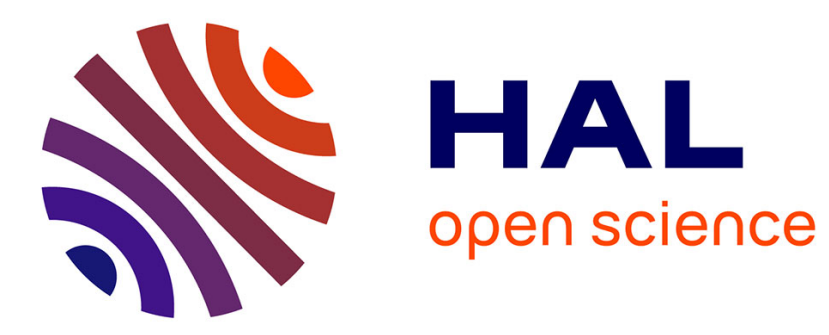

\title{
High Damping Fe-Cr-Mn Alloy
}

\author{
N. Igata, H. Aoyama, Y. Kanja, Y. Habara
}

\section{To cite this version:}

N. Igata, H. Aoyama, Y. Kanja, Y. Habara. High Damping Fe-Cr-Mn Alloy. Journal de Physique IV Proceedings, 1996, 06 (C8), pp.C8-791-C8-794. 10.1051/jp4:19968169 . jpa-00254604

\section{HAL Id: jpa-00254604 https://hal.science/jpa-00254604}

Submitted on 1 Jan 1996

HAL is a multi-disciplinary open access archive for the deposit and dissemination of scientific research documents, whether they are published or not. The documents may come from teaching and research institutions in France or abroad, or from public or private research centers.
L'archive ouverte pluridisciplinaire HAL, est destinée au dépôt et à la diffusion de documents scientifiques de niveau recherche, publiés ou non, émanant des établissements d'enseignement et de recherche français ou étrangers, des laboratoires publics ou privés. 


\title{
High Damping Fe-Cr-Mn Alloy
}

\author{
N. Igata, H. Aoyama*, Y. Kanja and Y. Habara* \\ Department of Materials Science and Technology, Science University of Tokyo, 2641 Yamazaki, Noda, \\ Chiba 278, Japan \\ * Research and Development Department, Nippon Metal Industry Co., Ltd. 1-30 Ohyama, Sagamihara, \\ Kanagawa 229, Japan
}

\begin{abstract}
Internal friction of Fe-Cr-Mn alloys have close relations with chemical compositions, constituent phases and cold work degree. In Fe-Cr-Mn alloys, phases are composed from $\gamma, \varepsilon$ and $\alpha$ depending on chemical compositions. In solution annealed specimens, internal friction was higher when $\alpha$ phase was included. This suggests that $\alpha$ phase behaves as ferromagnetic phase and also introduces fresh dislocation surrounding it. In cold worked specimens, internal friction increases dependent on cold work degree and it was became highest when $\varepsilon$ phase is maximum. This result suggests that the stacking fault energy is minimum in this case, and the extended half dislocations are more mobile than other cases. In cold worked specimens the contribution of $\alpha$ phase was negligible. This alloy has damping capacity higher than $1 \%$, with high strength (more than $1000 \mathrm{MPa}$ ) and high corrosion resistance.
\end{abstract}

\section{INTRODUCTION}

Recently high damping materials have been developed along composite materials, however there have been problems in corrosion resistance and strength. If we can get high damping alloy with both high corrosion resistance and high strength, it would be very useful. Fe-Cr-Mn alloy is the candidate alloy because it is composed from three phases $\gamma(\mathrm{fcc}), \varepsilon(\mathrm{hcp})$ and $\alpha(\mathrm{bcc})$ and its stacking fault energy is minimum when $\varepsilon$ phase is maximum. In this study high damping Fe-Cr-Mn stainless steel was investigated by the control of microstructures and the mechanism was discussed.

\section{EXPERIMENTAL PROCEDURES}

\subsection{Materials}

The materials used were 7 types of $\mathrm{Fe}-\mathrm{Cr}$-Mn stainless steels containing $11 \% \sim 12 \% \mathrm{Cr}$ and different levels of manganese (R-1 R-4) and nitrogen $(\mathrm{N}-1 \sim \mathrm{N}-3)$ considering the different composition of $\gamma, \varepsilon$ and $\alpha$ phases. The chemical compositions are shown in Table 1. Each of these materials was solution annealed at $1323 \mathrm{~K}$ for $150 \mathrm{~s}$ and cold work was given by rolling until $50 \%$ reduction. For R-3, cold work degree was varied from $5 \% \sim 50 \%$ in order to investigate the effect of cold work on damping characteristics. Fe-Cr-Ni stainless steels were also used as reference materials.

Table 1 Chemical composition of materials used

\begin{tabular}{|c|c|c|c|c|c|c|c|c|c|c|c|}
\hline & $\mathrm{C}$ & $\mathrm{Si}$ & $\mathrm{Mn}$ & $\mathrm{P}$ & $\mathrm{S}$ & $\mathrm{Ni}$ & $\mathrm{Cr}$ & $\mathrm{Mo}$ & $\mathrm{Cu}$ & $\mathrm{N}$ & $\mathrm{Fe}$ \\
\hline $\mathrm{R}-1$ & 0.007 & 0.73 & 14.82 & $<0.001$ & 0.003 & $<0.01$ & 11.53 & $<0.01$ & 0.01 & 0.011 & bal. \\
\hline $\mathrm{R}-2$ & 0.005 & 0.48 & 16.48 & $<0.001$ & 0.002 & 0.01 & 11.87 & $<0.01$ & 0.01 & 0.020 & bal. \\
\hline $\mathrm{R}-3$ & 0.010 & 0.45 & 21.54 & $<0.001$ & 0.002 & 0.01 & 11.88 & $<0.01$ & 0.01 & 0.033 & bal. \\
\hline $\mathrm{R}-4$ & 0.009 & 0.42 & 31.32 & $<0.001$ & 0.002 & $<0.01$ & 11.61 & $<0.01$ & 0.01 & 0.055 & bal. \\
\hline $\mathrm{N}-1$ & 0.017 & 0.32 & 12.76 & 0.014 & 0.001 & 0.05 & 12.02 & 0.01 & 0.01 & 0.042 & bal. \\
\hline $\mathrm{N}-2$ & 0.012 & 0.30 & 12.84 & 0.006 & 0.003 & 0.03 & 11.86 & 0.01 & 0.01 & 0.140 & bal. \\
\hline $\mathrm{N}-3$ & 0.011 & 0.39 & 12.50 & 0.001 & 0.002 & 0.07 & 11.63 & 0.01 & 0.01 & 0.200 & bal. \\
\hline Type 301 & 0.090 & 0.60 & 0.97 & - & - & 7.17 & 17.10 & 0.11 & 0.23 & 0.050 & bal. \\
\hline Type 304 & 0.060 & 0.63 & 0.98 & - & - & 8.19 & 18.40 & 0.27 & 0.34 & 0.060 & bal. \\
\hline Type 316 & 0.060 & 0.74 & 1.02 & - & - & 10.2 & 17.10 & 2.21 & 0.25 & 0.030 & bal. \\
\hline
\end{tabular}




\subsection{Experimental Method}

In order to investigate damping characteristics, internal friction $\mathrm{Q}^{-1}$ was measured at temperatures from 123 to $372 \mathrm{~K}$ using the transversal vibration technique. The frequency was $\sim 700 \mathrm{~Hz}$. The specimens size for internal friction was $1 \mathrm{~mm} \times 10 \mathrm{~mm} \times 120 \mathrm{~mm}$. The content of constituent phases such as $\gamma, \varepsilon$ and $\alpha$ were measured by $\mathrm{X}$ ray [1]. The dislocation density of each phase are determined by transmission electror microscope.

\section{RESULTS AND DISCUSSION}

\subsection{Effect of $\mathrm{Mn}$ and $\mathrm{N}$ on phase compositions and internal friction}

Fig. 1 and Fig.2 show the phase compositions as the function of $\mathrm{Mn}$ content before and after cold work respectively. As shown in these figures, $\gamma$ phase increases and $\alpha$ phase decreases with Mn content, but $\varepsilon$ phase increases and decreases with Mn content and at Mn 20\% $\varepsilon$ phase shows the maximum. The stacking fault energy is closely related to $\varepsilon$ phase, and it is minimum when $\varepsilon$ phase is maximum. Fig. 3 and Fig. 4 show the internal friction of solution annealed and cold worked $R$ series specimens respectively. R-3 showec the maximum internal friction at room temperature. Fig.5 shows the phase compositions before and after cold work as the function of $\mathrm{N}$ contents and Fig. 6 shows the internal friction of solution annealed and colc worked $\mathrm{N}$ series specimens respectively. Fig. 7 shows the height of internal friction at room temperature or:

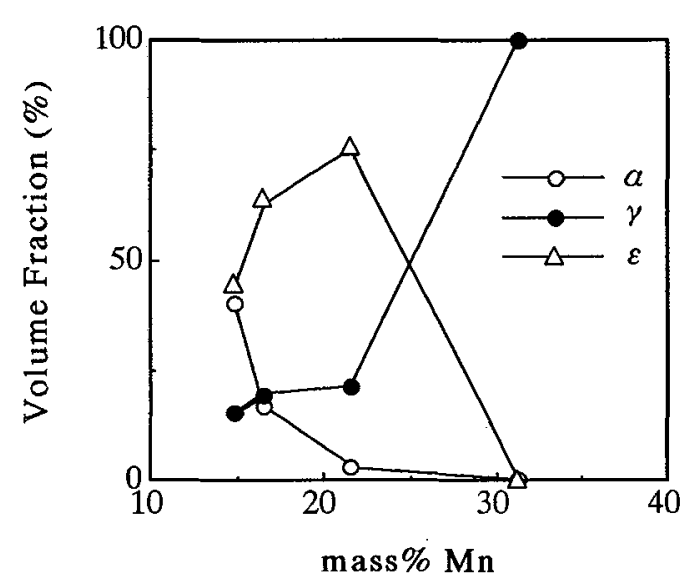

Fig.1 Volume fraction of each phase in solution annealed state(R-1 R-4)

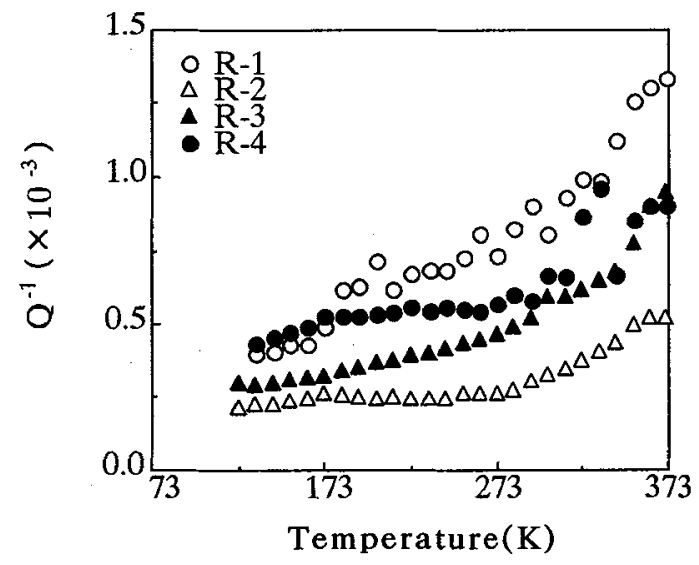

Fig.3 Internal friction in solution annealed state( $(\mathrm{R}-1 \sim \mathrm{R}-4)$

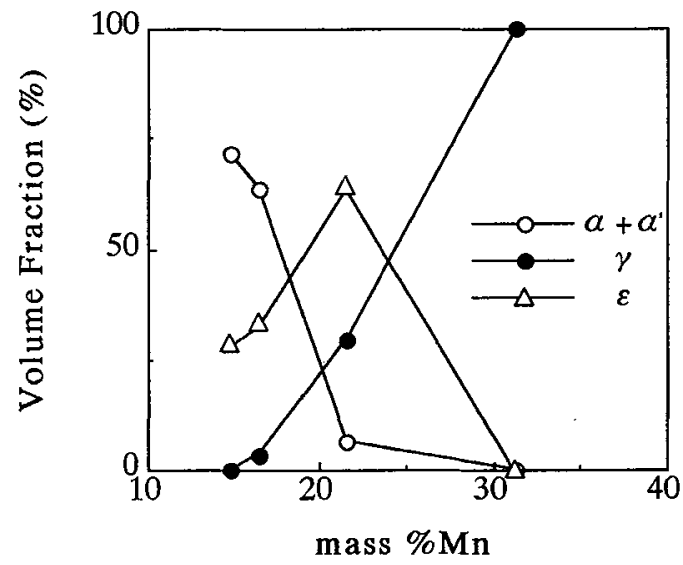

Fig.2 Volume fraction of each phase in cold worked state $(R-1 \sim R-4)$

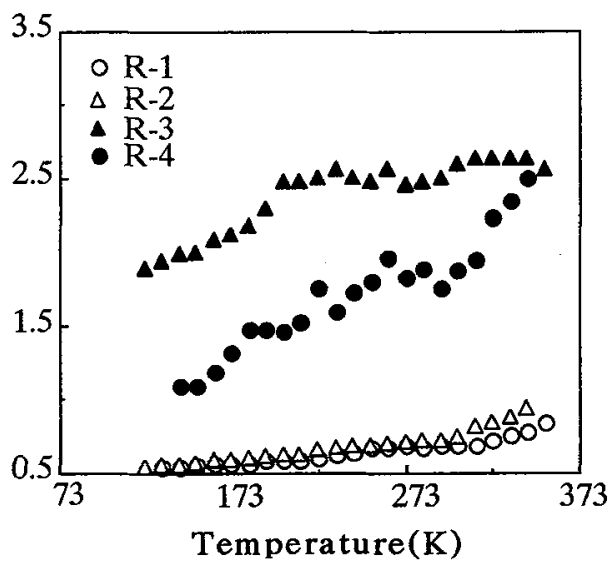

Fig.4 Internal friction in cold worked state( $R-1 \sim R-4)$ 


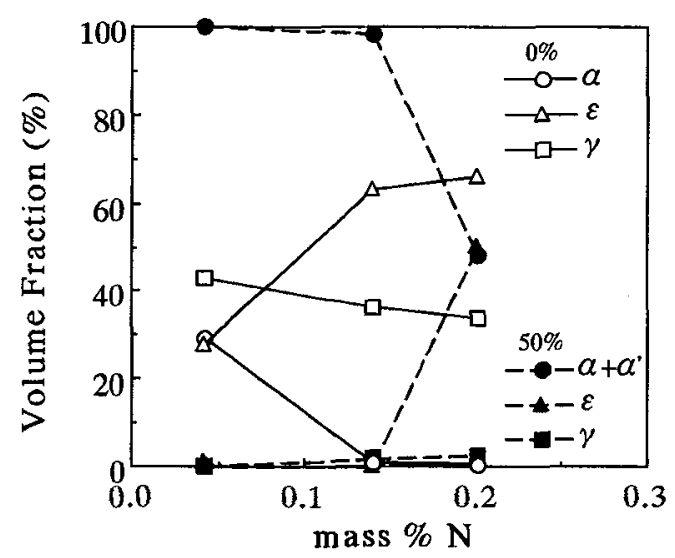

Fig.5 Volume fraction of each phase in solution annealed and cold worked state $(\mathrm{N}-1 \sim \mathrm{N}-3)$

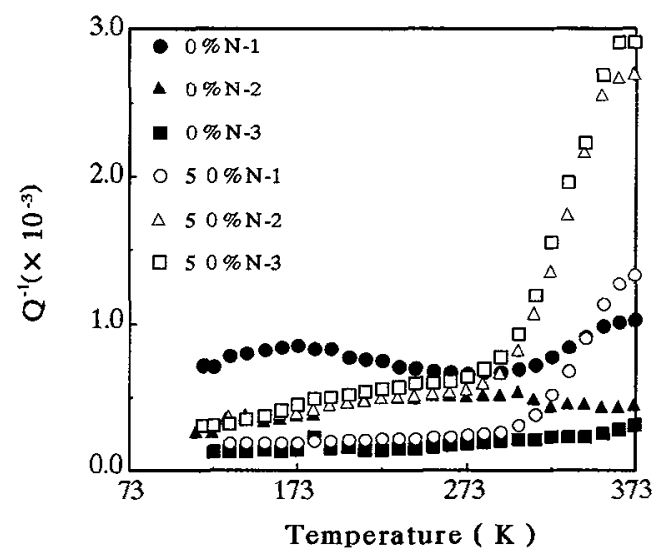

Fig.6 Internal friction in solution annealed and cold worked state $(\mathbf{N}-1 \sim \mathbf{N}-3)$

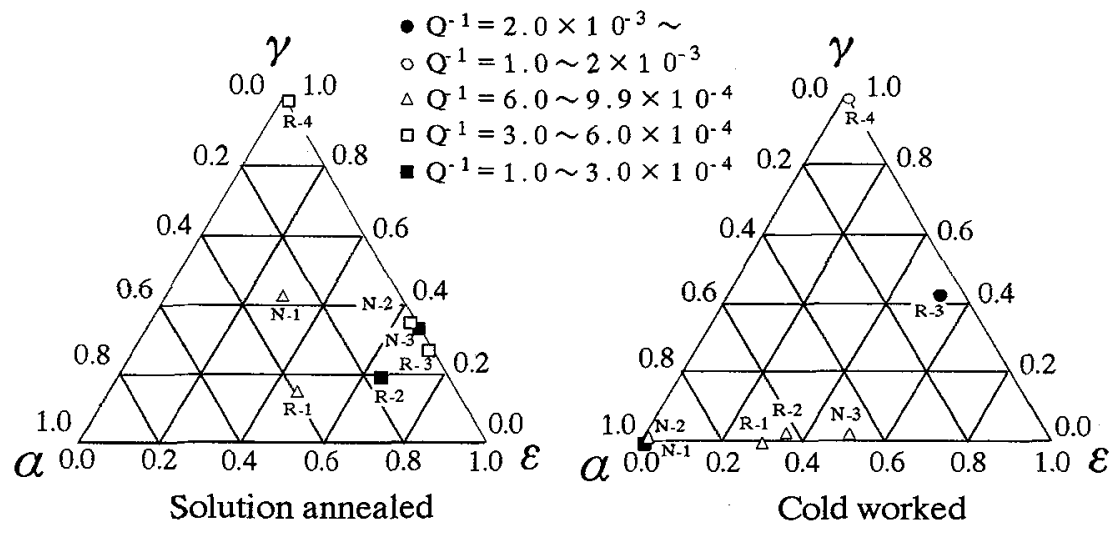

Fig.7 Constituent phases in all specimens

the map of three constituent phases. This shows that internal friction is higher in cold worked state. In solution annealed specimen $\alpha$ phase is effective in increasing internal friction but ineffective in cold worked specimen. In cold worked state, the $\varepsilon$ phase is effective in increasing internal friction. This suggests that dislocation in $\gamma$ and $\varepsilon$ phases are extended due to low stacking fault energy and half dislocation are more mobile in $\varepsilon$ or $\gamma$ or at interface of $\varepsilon / \gamma$ phases. But in solution annealed condition $\varepsilon, \gamma$ phases are not effective which may be due to dislocation pinning by solute atoms. As for the effect of $\alpha$, in solution annealed specimen, the magnetic damping or fresh dislocations introduced by $\alpha$ phase would contribute to internal friction, but in cold worked specimens those factors would become ineffective.

\subsection{Effect of cold work on $R-3$ specimen}

After cold work, the dislocation density gradually increased dependenting on the cold work degree (see Fig.8) and internal friction at room temperature increased as well as shown in Fig.9. This shows that the increase of internal friction in R-3 comes from dislocation in $\gamma$ and $\varepsilon$ phases. For comparison the internal friction of other $\mathrm{Fe}-\mathrm{Cr}-\mathrm{Mn}$ alloys and $\mathrm{Fe}-\mathrm{Cr}-\mathrm{Ni}$ alloys are shown in Fig.10 as the function of cold work degree. In cold worked alloys which includes $\alpha$ phases, internal friction decreases. The R-3 alloy which included $20 \% \mathrm{Mn}$ showed the maximum internal friction. It is considered that the stacking fault energy is lower in R-3 because of maximum $\varepsilon$ content in $\gamma$ phase, and it contributes to internal friction. In $\mathrm{Fe}-\mathrm{Cr}-\mathrm{Ni}$, after cold work the free energy drop from $\gamma$ to $\alpha$ phase is larger than that from $\gamma$ to $\varepsilon$ phase and $\gamma \rightarrow \alpha$ reaction occurs. In this case, the $\alpha$ phase increases with a decrease of the $\varepsilon$ and $\gamma$ phase. Since the contribution of the $\alpha$ phase to the internal friction is negligible in cold worked state, the internal friction of cold worked Fe-CI- 


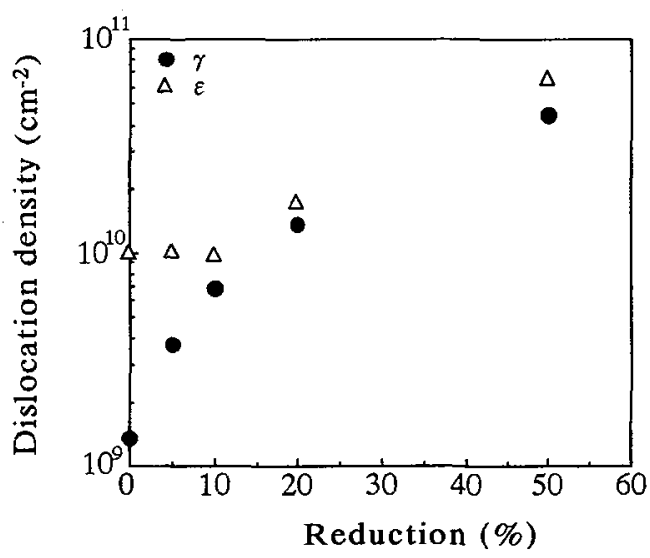

Fig.8 Dislocation density in $\gamma$ and $\varepsilon$ phases (R-3)

$\mathrm{Ni}$ is smaller.

\subsection{Damping capacity and strength compared with other alloys}

Fig.11 shows the mapping of damping capacity and strength of stainless steels [2]. Hitherto there have been many alloys, however above the strength level of $1000 \mathrm{MPa}$, there have been no data until now. We could get high damping (damping capacity $>1 \%$ ) with high strength and high corrosion resistance. The damping capacity is higher in Fe$\mathrm{Cr}-\mathrm{Mn}$ than in $\mathrm{Fe}-\mathrm{Cr}-\mathrm{Ni}$ alloys.

\section{CONCLUSION}

Damping behavior of $\mathrm{Fe}-\mathrm{Cr}-\mathrm{Mn}$ alloys is investigated. From experimental results, several conclusions are obtained as follows :

(1) The variation of three phases $(\gamma+\varepsilon+\alpha)$ were observed depending on $\mathrm{Mn}, \mathrm{N}$ content and cold work degree.

(2) In R-3, the increase of $Q^{-1}$ value $(5 \sim 50 \%$ cold worked) was observed with the increase of dislocation density in $\gamma, \varepsilon$ phases.

(3) $50 \%$ cold worked R-3 which included $20 \% \mathrm{Mn}$ showed the maximum damping. This is attributed to dislocations in $y$ and $\varepsilon$ phases in which stacking fault energy is low.

(4) The obtained damping capacity was larger than $1 \%$ at the strength level of $1300 \mathrm{MPa}$, in $\mathrm{Fe}-\mathrm{Cr}$ $\mathrm{Mn}(\mathrm{R}-3) 50 \%$ cold worked.

\section{References}

[1] N.Fujino, Y. Matumoto and Y. Maehara ; Iron and Steel, 11,2040 (1981)

[2] K.Sugimoto ; Iron and Steel, 14, 2204 (1974)

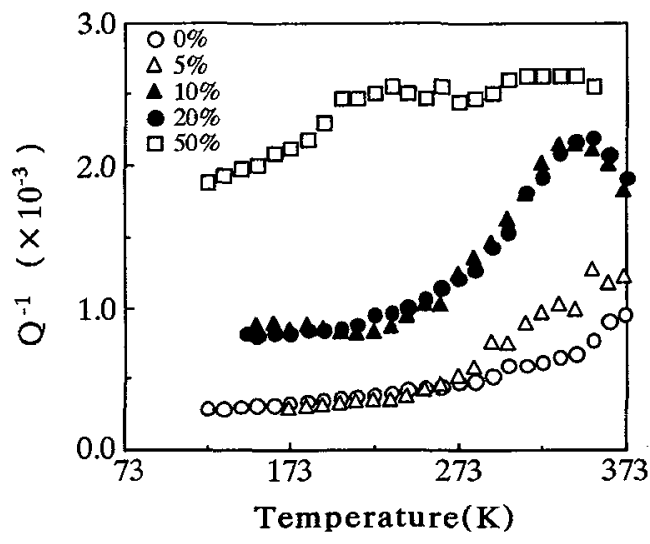

Fig.9 Internal friction in $0 \% \sim 50 \%$ cold worked state (R-3)

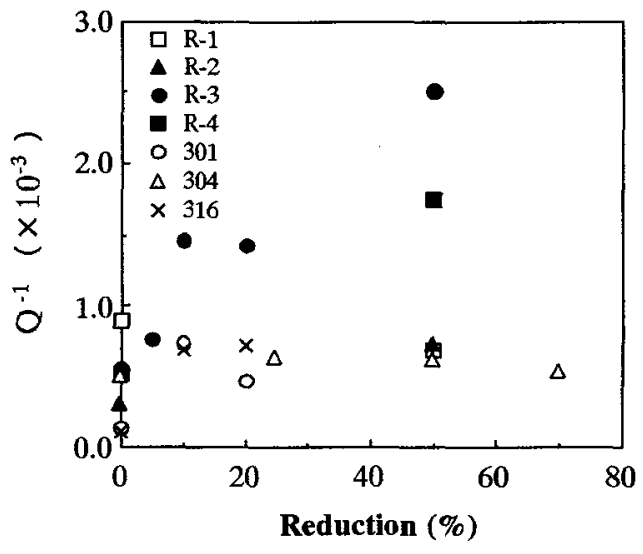

Fig.10 Internal friction of $\mathrm{Fe}-\mathrm{Cr}-\mathrm{Mn}$ and $\mathrm{Fe}-\mathrm{Cr}$-Ni at room temperature as the function of cold work degree

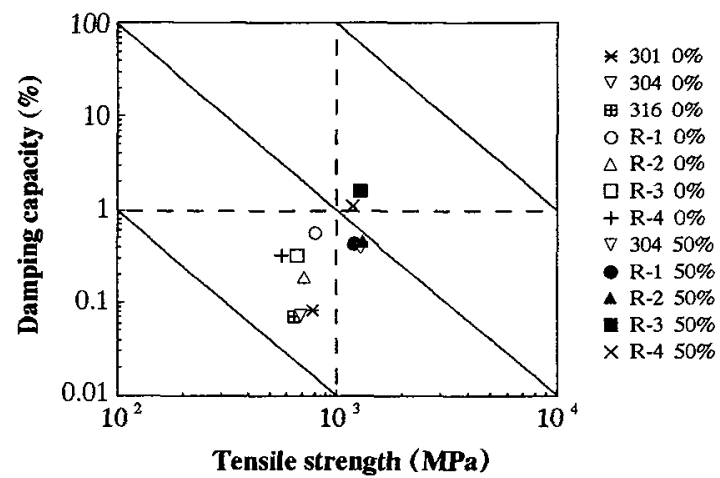

Fig.11 Damping capacity as the function of tensile strength 